\title{
Exploring New Partners for the Domino $\alpha$-Arylation/Michael Addition Reaction Leading to Tetrahydroisoquinolines
}

\author{
Daniel Solé, ${ }^{*[a]}$ Ferran Pérez-Janer, ${ }^{[a]}$ Yago García-Rodeja,${ }^{[b]}$ and Israel Fernández ${ }^{*[b]}$
}

\begin{abstract}
Sulfonates, sulfonamides and phosphonates are useful nucleophiles for palladium-catalyzed intramolecular $\alpha$-arylation leading to tetrahydroisoquinolines. While the sulfonate $\alpha$-arylation can be successfully combined in a domino process with a broad range of Michael acceptors, only vinyl sulfones can be used in Michael additions when starting from sulfonamides. No domino process was developed with the phosphonate derivative. Density functional theory (DFT) calculations were carried out to gain more insight into the experimental differences observed in the reactions involving these substrates.
\end{abstract}

\section{Introduction}

In the continuous search for more environmentally friendly reaction processes, domino reactions have emerged as a powerful tool for synthetic organic chemists. ${ }^{[1]}$ Ideally, a multicomponent domino process would simply involve the mixing of all the reagents, which would then participate chemoselectively in a particular sequence of events leading to the final product without requiring any additional modification of the reaction conditions. ${ }^{[2]}$ The advantages of domino strategies include lower costs, a more expeditious procedure, less purification, and often higher overall reaction yields.

In the last years, different domino processes combining palladium-catalyzed transformations with Michael addition reactions have been developed for the synthesis of a variety of aza-heterocycles. ${ }^{[3]}$ In this context, we have recently reported efficient syntheses of highly functionalized tetrahydroisoquinolines ${ }^{[4]}$ and indoles ${ }^{[5]}$ by domino azaMichael/Pd-catalyzed $\alpha$-arylation/Michael addition processes based on the use of sulfones both as electrophiles and nucleophiles. To further generalize the application of these synthetic methodologies and access diversely functionalized

[a] D. Solé, F. Pérez-Janer

Laboratori de Química Orgànica, Facultat de Farmàcia,

Universitat de Barcelona

Av. Joan XXIII 27-31, 08028 Barcelona, Spain

E-mail: dsole@ub.edu

http://www.ub.edu/farmaco/ca/quimica/llistat_recerca

[b] Y. García-Rodeja, I. Fernández

Departamento de Química Orgánica I, Facultad de Ciencias

Químicas,

Universidad Complutense de Madrid

Ciudad Universitaria, 28040 Madrid, Spain

E-mail: israel@quim.ucm.es

http://www.ucm.es/info/biorgmet/espanol/isra.html

Supporting information for this article is given via a link at the end of the document. heterocycles, we were interested in exploring the feasibility of other electron-withdrawing groups in the domino $\alpha$ arylation/Michael addition strategy.

In this paper, we expand our previous studies towards the use of sulfonates, sulfonamides ${ }^{[6]}$ and phosphonates ${ }^{[7]}$ as nucleophiles in the $\alpha$-arylation ${ }^{[8]}$ step of the domino process leading to tetrahydroisoquinolines ${ }^{[9]}$ (Scheme 1 ). The combined experimental and computational study of these reactions establishes the scope and limitations of these electronwithdrawing groups as alternatives to sulfones.

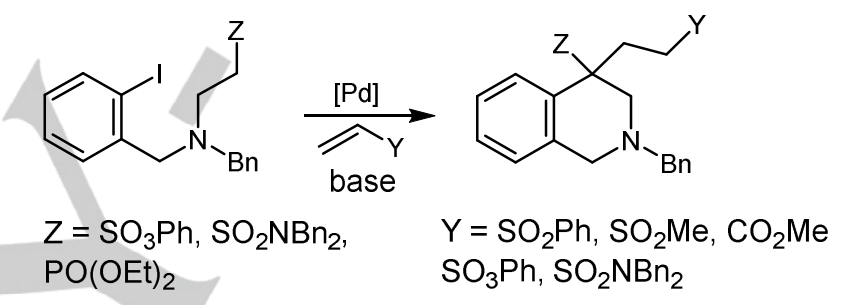

Scheme 1. Domino $\alpha$-arylation/Michael addition process.

\section{Results and Discussion}

In our previous work on the $\alpha$-arylation/Michael addition domino process, we realized that the $\mathrm{Pd}$-catalyzed reaction constituted the most challenging step of the entire transformation. Thus, we first examined the $\alpha$-arylation of sulfonate $\mathbf{1 a}$, sulfonamides $\mathbf{1 b}$ and $\mathbf{1 d}$, and phosphonate $\mathbf{1 c}$ (Table 1).

Treatment of 1a with $\mathrm{Pd}_{2}(\mathrm{dba})_{3} /$ xantphos as the catalyst and $\mathrm{K}_{3} \mathrm{PO}_{4}$ as the base in THF, an effective combination for the intramolecular $\alpha$-arylation of $\beta$-amino sulfones, ${ }^{[4]}$ afforded tetrahydroisoquinoline $\mathbf{2 a}$ in a modest $27 \%$ yield (entry 1 ). While exchanging the solvent for toluene increased the yield up to $45 \%$ (entry 2), changing the base to $\mathrm{Cs}_{2} \mathrm{CO}_{3}$ resulted in the complete decomposition of the material. In this context, it should be noted that 2a was rather unstable and partially decomposed during the chromatographic purification, as evidenced by the isolation of significant amounts of phenol.

The reaction of sulfonamide $\mathbf{1 b}$ using the couple $\mathrm{Pd}_{2}(\mathrm{dba})_{3} /$ xantphos and $\mathrm{K}_{3} \mathrm{PO}_{4}$ in THF led to the desired tetrahydoisoquinoline $\mathbf{2 b}$ in $46 \%$ yield (entry 3 ). Interestingly, performing the $\alpha$-arylation of $\mathbf{1 b}$ using $\mathrm{Cs}_{2} \mathrm{CO}_{3}$ as the base afforded $\mathbf{2 b}$ in $\mathbf{7 5} \%$ yield (entry 4 ). Treatment of phosphonate $\mathbf{1 c}$ under the same reaction conditions gave $2 \mathrm{c}$ in $61 \%$ yield (entry 5). The use of $\mathrm{PPh}_{3}$ as the ligand instead of xantphos afforded a similar result (entry 6), while $\mathrm{PCy}_{3}$ increased the yield considerably up to $80 \%$ (entry 7 ). The use of $\mathrm{K}_{3} \mathrm{PO}_{4}$ as the base, 
maintaining the same combination of $\mathrm{Pd}$ source and ligand, resulted in a slower reaction (entry 8 ).

Table 1. Pd-catalyzed $\alpha$-arylation of 1a-c. ${ }^{[a]}$<smiles>[Z]CCN(Cc1ccccc1)Cc1ccccc1I</smiles>

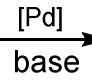

1a, $\mathrm{Z}=\mathrm{SO}_{3} \mathrm{Ph}$

1b, $\mathrm{Z}=\mathrm{SO}_{2} \mathrm{NBn}_{2}$

1c, $Z=\mathrm{PO}(\mathrm{OEt})_{2}$

$1 \mathrm{~d}, \mathrm{Z}=\mathrm{SO}_{2} \mathrm{NHBn}$<smiles>CC1CN(Br)Cc2ccccc21</smiles>

$2 a$

2b

2c (entry 1). A similar reaction was observed when using methyl vinyl sulfone as the Michael acceptor, which afforded $\mathbf{3 a b}$ in $70 \%$ yield (entry 2). The $\alpha$-arylation/conjugated addition tandem process was also possible when using methyl acrylate, phenyl ethenesulfonate and $N, N$-dibenzylethenesulfonamide, which allowed us to prepare 3ac, 3ad, and 3ae, respectively, in moderate yields (entries 3-5). It should be noted that, except when using $\mathrm{N}, \mathrm{N}$-dibenzylethenesulfonamide as the Michael acceptor, the domino reactions from 1a proceeded with higher yields than the $\alpha$-arylation, confirming that the observed lower yield of the latter is partially due to the degradation of the arylated sulfonate $\mathbf{2 a}$ under the reaction conditions.

Table 2. Tandem $\alpha$-arylation/Michael addition reactions. ${ }^{[a]}$

\begin{tabular}{llllll}
\hline Entry & $\mathbf{1}$ & $\begin{array}{l}{[\mathrm{Pd}] / \text { ligand }} \\
(\mathrm{mol} \%)\end{array}$ & Base & Solvent & $\begin{array}{l}\text { Products } \\
(\text { yield })^{[\mathrm{b}]}\end{array}$ \\
\hline 1 & $\mathbf{1 a}$ & $\begin{array}{l}\mathrm{Pd}_{2}(\mathrm{dba})_{3}(7.5) \\
\text { xantphos }(15)\end{array}$ & $\mathrm{K}_{3} \mathrm{PO}_{4}$ & THF & $\mathbf{2 a ~}(27 \%)^{[\mathrm{c}]}$ \\
2 & $\mathbf{1 a}$ & ${\mathrm{Pd}\left(\mathrm{PPh}_{3}\right)_{4}(10)}$ & $\mathrm{K}_{3} \mathrm{PO}_{4}$ & toluene & $\mathbf{2 a ~}(45 \%)^{[\mathrm{c}][\mathrm{d}]}$
\end{tabular}

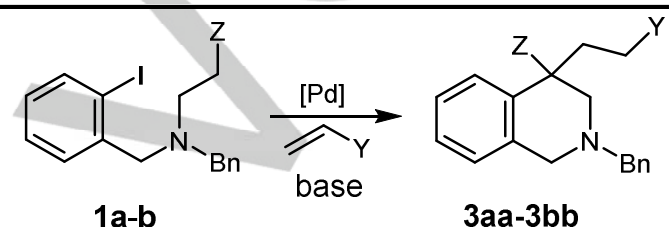

1a-b 3aa-3bb

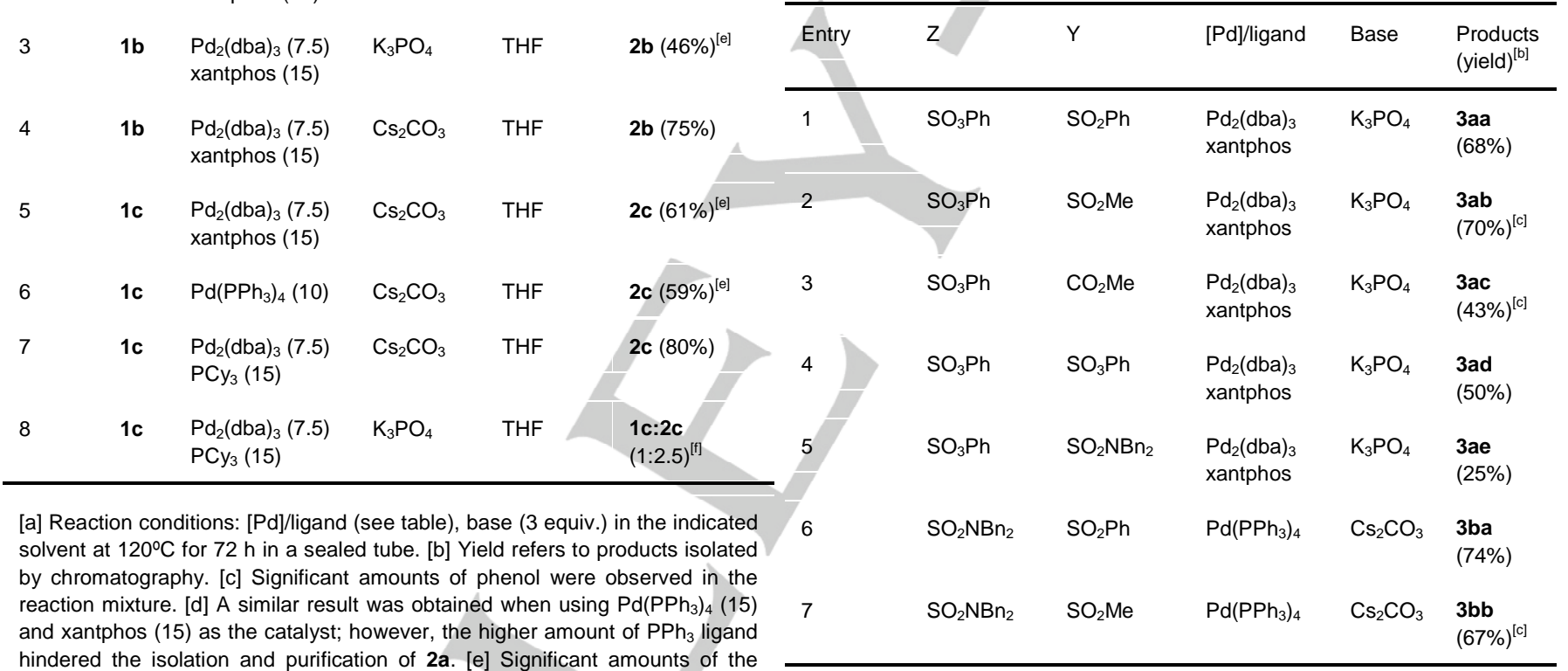
corresponding hydrodehalogenation product were observed in the reaction mixture. [f] ${ }^{1} \mathrm{H}$ NMR ratio, yields were not quantified.

[a] Reaction conditions: [Pd] (10\%), ligand (10\%), base (3 equiv.), and Michael acceptor ( 1.5 equiv.) in THF at $120^{\circ} \mathrm{C}$ in a sealed tube for $72 \mathrm{~h}$. [b] Yield refers to products isolated by chromatography. [c] Michael acceptor (3 equiv.).

Finally, sulfonamide $\mathbf{1 d}$, which has an acidic $\mathrm{H}$ atom at the nitrogen, failed to undergo a similar $\alpha$-arylation, and was recovered unaltered under all explored reaction conditions.

The results in Table 1 show that sulfonates, sulfonamides as well as phosphonates can undergo $\alpha$-arylation and, consequently, they are all potential candidates for the proposed domino cascades. We therefore decided to explore the $\alpha$ arylation/Michael addition domino process using these substrates with a variety of Michael acceptors (Table 2).

Gratifyingly, treatment of sulfonate 1a with a catalytic amount of $\mathrm{Pd}\left(\mathrm{PPh}_{3}\right)_{4} / x a n t p h o s$ and $\mathrm{K}_{3} \mathrm{PO}_{4}$ in the presence of phenyl vinyl sulfone in THF afforded sulfonate 3 aa in $68 \%$ yield
In the tandem reactions, sulfonamide $\mathbf{1 b}$ afforded parallel results to sulfonate 1a with phenyl vinyl sulfone and methyl vinyl sulfone (entries 6-7), but no product was formed when using methyl acrylate, phenyl ethenesulfonate and $N, N$ dibenzylethenesulfonamide as the Michael acceptor, and only the $\alpha$-arylation product $\mathbf{2 b}$ was isolated. Similarly, phosphonate 1c also failed to undergo the $\alpha$-arylation/conjugated addition tandem process with any of the Michael acceptors explored herein. Once again, the corresponding $\alpha$-arylation compound $\mathbf{2 c}$ was the only product isolated in the reaction mixtures. 
It is noteworthy that in all domino reactions with $\mathbf{1 a}$ and $\mathbf{1 b}$, the $\alpha$-arylation took place without any interference from the competing Heck reaction, which agrees with the unfeasibility previously observed for this particular pathway when using sulfones in the domino process. ${ }^{[5]}$

According to our previous study involving 2-iodoanilines and sulfones, ${ }^{[5]}$ two alternative reaction pathways for the above palladium-catalyzed $\alpha$-arylation reactions leading to the observed tetrahydroisoquinolines $\mathbf{2}$ can be envisaged: the direct base-mediated $\alpha$-arylation reaction and a concerted metalation- deprotonation (CMD) $\mathrm{C}-\mathrm{H}$ activation process. The competition between the two pathways in the reactions involving the new nucleophiles was explored computationally by means of density functional theory calculations. ${ }^{[10]}$ To this end, we computed the corresponding reaction profiles starting from INTO, the intermediate formed after a model benzylamine derivative (in which the benzyl group attached to the nitrogen atom was replaced by a methyl group) underwent oxidative addition to the model $\mathrm{Pd}\left(\mathrm{PMe}_{3}\right)_{2}$ catalyst, in the presence of carbonate as the base.

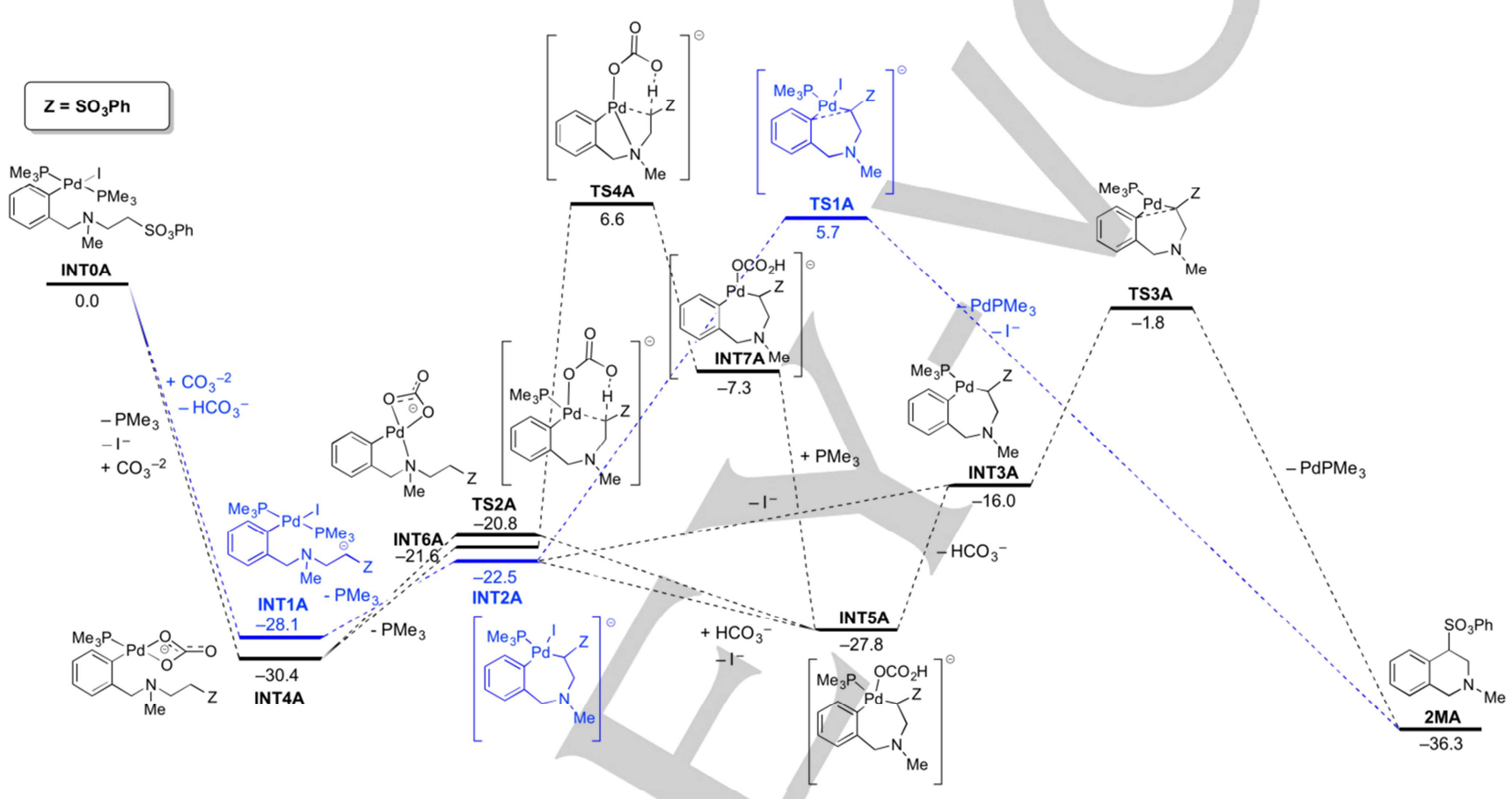

Figure 1. Computed reaction profiles for the palladium catalyzed $\alpha$-arylation reaction of INTOA. Relative free energies ( $\triangle \mathrm{G}$, at $298 \mathrm{~K})$ and bond distances are given in $\mathrm{kcal} / \mathrm{mol}$ and angstroms, respectively. All data were computed at the PCM(tetrahydrofuran)-B3LYP-D3/def2-TZVP//PCM(tetrahydrofuran)-B3LYPD3/def2-SVP level.

Figure 1 shows the reaction profiles for the process involving INTOA $\left(\mathrm{Z}=\mathrm{SO}_{3} \mathrm{Ph}\right)$. The base-mediated $\alpha$-arylation pathway (in blue) begins with the base-mediated deprotonation of the acidic hydrogen atom at the carbon atom linked to the sulfonate group, therefore leading to the carbanionic intermediate INT1A in a strongly exergonic process $\left(\Delta G_{R}=-\right.$ $28.1 \mathrm{kcal} / \mathrm{mol}$ ). This species would then evolve to complex INT2A by the slightly endergonic $\left(\Delta G_{R}=5.6 \mathrm{kcal} / \mathrm{mol}\right)$ coordination of the carbanion to the transition metal and concomitant release of a phosphine ligand. This step typically proceeds with the initial endergonic release of the phosphine ligand to produce a coordination vacant which is then saturated by the carbanionic ligand. The latter intramolecular coordination is typically associated with a low barrier $(<10 \mathrm{kcal} / \mathrm{mol})^{[11]}$ and therefore, it does not constitute the rate-limiting step of the transformation. The reductive elimination reaction would then take place to produce the tetrahydroisoquinoline 2MA. This exergonic step $\left(\Delta \mathrm{G}_{\mathrm{R}}=-13.8 \mathrm{kcal} / \mathrm{mol}\right)$ proceeds via TS1A, a transition state associated with the direct formation of the new C-C bond, with a relatively high activation barrier of 28.2 $\mathrm{kcal} / \mathrm{mol}$. A similar activation barrier of $28.6 \mathrm{kcal} / \mathrm{mol}$ was computed for the strongly related direct $\alpha$-arylation reaction involving 2-iodoaniline derivatives with $\mathrm{Z}=\mathrm{SO}_{2} \mathrm{Me},{ }^{[5]}$ thus indicating that neither the substrate nor the $Z$ group has a significant influence on this reaction step. Alternatively, INT2A can be transformed into the coordinatively unsaturated complex INT3A by releasing the iodide ligand in an endergonic process $\left(\Delta \mathrm{G}_{\mathrm{R}}=6.5 \mathrm{kcal} / \mathrm{mol}\right)$. This species would be then converted into the final reaction product $\mathbf{2}$ MA in a highly exergonic transformation $\left(\Delta G_{R}=-20.3 \mathrm{kcal} / \mathrm{mol}\right)$ through TS3A with a much lower activation barrier of $14.2 \mathrm{kcal} / \mathrm{mol}$. 
The alternative reaction pathway involving the $\mathrm{C}-\mathrm{H}$ activation begins with the also highly exergonic $\left(\Delta G_{R}=-30.4\right.$ $\mathrm{kcal} / \mathrm{mol}$ ) replacement of the iodide and phosphine ligand in INTOA by the bidendate $\mathrm{CO}_{3}{ }^{-2}$ ligand, thus forming the anionic complex INT4A. A concerted metalation deprotonation (CMD) $\mathrm{C}-\mathrm{H}$ activation reaction assisted by the carbonate ligand then occurs to produce INT5A in a slightly endergonic transformation $\left(\Delta \mathrm{G}_{\mathrm{R}}=2.6 \mathrm{kcal} / \mathrm{mol}\right)$. Strikingly, this reaction step proceeds with an activation barrier of only $9.6 \mathrm{kcal} / \mathrm{mol}$ (via TS2A), which is much lower than that computed not only for the direct $\alpha$-arylation via TS1A (see above) but also for the analogous process involving 2-iodoaniline derivatives with $\mathrm{Z}=\mathrm{SO}_{2} \mathrm{Me}\left(\Delta \mathrm{G}^{\neq}=26.1\right.$ $\mathrm{kcal} / \mathrm{mol}) .^{[5]}$ Subsequent release of the $\mathrm{HCO}_{3}{ }^{-}$ligand would produce INT3A which, as mentioned above, readily evolves to the final reaction product via TS3A. Although, based on the computed relative activation barriers, our calculations suggest that the CMD pathway is strongly favored for the benzylamine derivative with $\mathrm{Z}=\mathrm{SO}_{3} \mathrm{Ph}$, the alternative INT1A $\rightarrow$ INT2A $\rightarrow$ INT5A or INT1A $\rightarrow$ INT2A $\rightarrow$ INT3A pathways cannot be completely discarded.

We also explored the analogous $\mathrm{C}-\mathrm{H}$ activation/reductive elimination sequence from INT6A, the intermediate formed upon coordination of the benzylic nitrogen atom to the transition metal in INT4A. However, the CMD reaction pathway from INT6A can be considered as non-competitive in view of the much higher activation barrier $\left(\Delta G^{\neq}=28.2 \mathrm{kcal} / \mathrm{mol}\right)$ and endergonicity $\left(\Delta G_{R}=\right.$ $14.3 \mathrm{kcal} / \mathrm{mol}$, from INT6A) computed for the corresponding CMD reaction via TS4A (see Figure 1 ).
These calculations indicate that the $\alpha$-arylation of sulfonate 1a in the presence of $\mathrm{Cs}_{2} \mathrm{CO}_{3}$ could proceed through the two competing mechanisms sharing the common intermediate INT3A, from which the reductive elimination affords the tetrahydroisoquinoline. As no $\alpha$-arylation product was isolated in the reactions of $1 \mathrm{a}$ when using $\mathrm{Cs}_{2} \mathrm{CO}_{3}$ as the base, we can conclude that the failure of the transformation has to be due to the instability of the arylated sulfone under the reaction conditions. In contrast, the $\alpha$-arylation of 1 a did take place when using $\mathrm{K}_{3} \mathrm{PO}_{4}$ as the base, and in this case, the reaction should follow the base-mediated pathway through INT1A.

Similar conclusions (i.e. preference of the $\mathrm{C}-\mathrm{H}$ activation) can be drawn for the analogous system with the phosphonate substituent $\left(Z=\mathrm{PO}(\mathrm{OMe})_{2}\right.$ in the calculations, see Figure $\mathrm{S} 1$ in the Supporting Information). In this particular transformation, although the CMD step proceeds with a higher activation barrier of $16.5 \mathrm{kcal} / \mathrm{mol}$, this pathway is still preferred over the direct $\alpha$ arylation reaction. Indeed, the corresponding transition state for the latter process (TS1C) lies $17.8 \mathrm{kcal} / \mathrm{mol}$ above that associated with the CMD reaction (TS2C, see Figure $\mathrm{S} 1$ ).

Thus, starting from phosphonate $1 \mathrm{c}$ and using $\mathrm{Cs}_{2} \mathrm{CO}_{3}$, the $\alpha$-arylated product $2 \mathrm{c}$ could be formed by both competing mechanisms, while in the presence of $\mathrm{K}_{3} \mathrm{PO}_{4}$, only the basemediated $\alpha$-arylation pathway would be operative.

The scenario involving the sulfonamide group $(Z=$ $\mathrm{SO}_{2} \mathrm{NMe}_{2}$ in the calculations) is slightly different to that found for $\mathrm{Z}=\mathrm{SO}_{3} \mathrm{Ph}$ or $\mathrm{PO}(\mathrm{OMe})_{2}$ (see Figure 2).

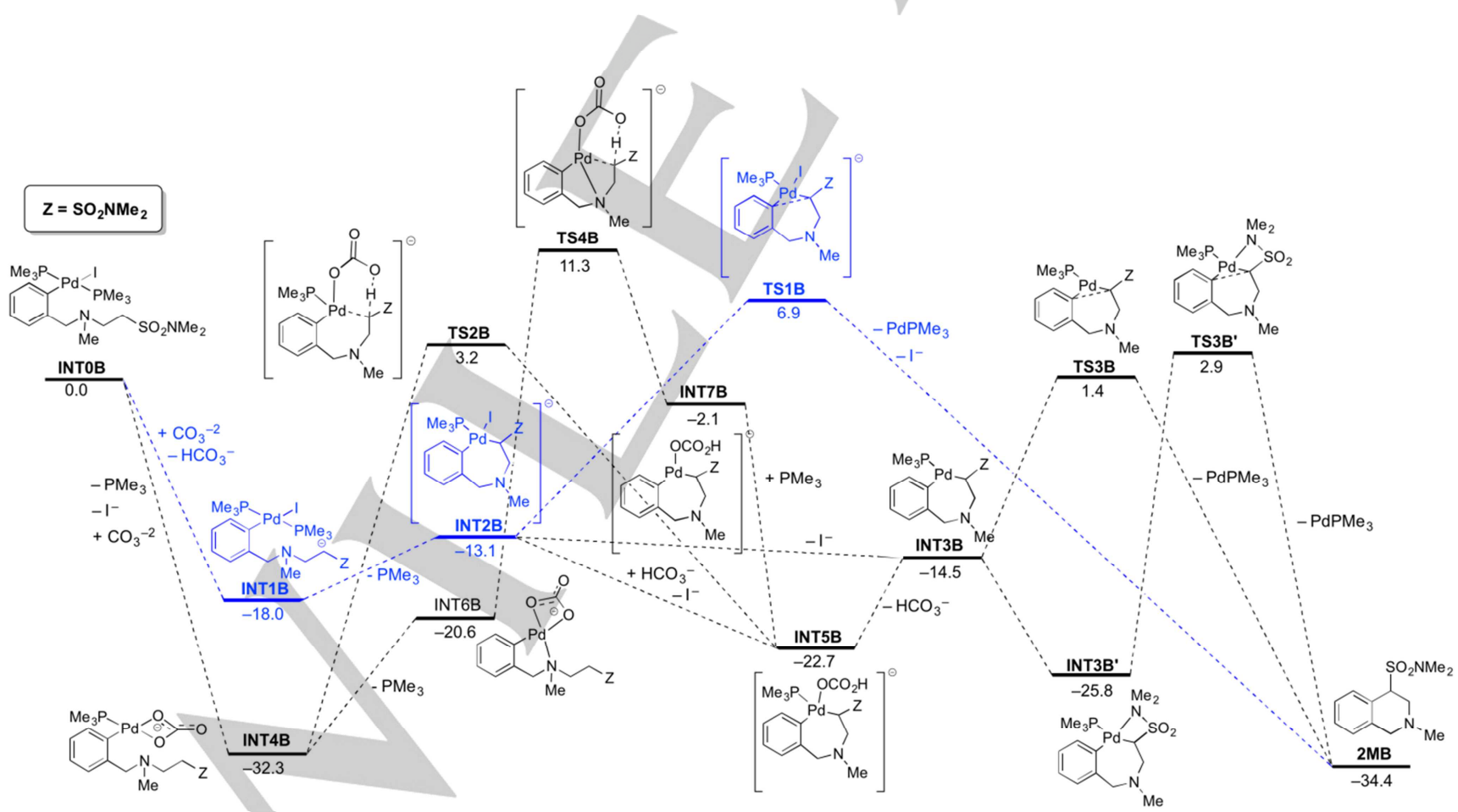

Figure 2. Computed reaction profiles for the palladium catalyzed $\alpha$-arylation reaction of INTOA. Relative free energies ( $\triangle \mathrm{G}$, at $298 \mathrm{~K})$ and bond distances are given in $\mathrm{kcal} / \mathrm{mol}$ and angstroms, respectively. All data were computed at the PCM(tetrahydrofuran)-B3LYP-D3/def2-TZVP//PCM(tetrahydrofuran)-B3LYPD3/def2-SVP level. 
Indeed, in this case, the corresponding CMD reaction step proceeds with a much higher activation barrier $\left(\Delta \mathrm{G}^{\neq}=35.5\right.$ $\mathrm{kcal} / \mathrm{mol}$, via TS2B), which makes this process unlikely. This is in part due to the higher $\mathrm{C}-\mathrm{H}$ bond strength in INT4B than in INT4A, as confirmed by the corresponding computed Wiberg bond indices ( 0.89 and 0.86 for INT4B and INT4A, respectively) and more likely due to higher pKa of the $\mathrm{R}-\mathrm{CH}_{2}-\mathrm{SO}_{2} \mathrm{NMe}_{2}$ species as compared to $\mathrm{R}-\mathrm{CH}_{2}-\mathrm{SO}_{3} \mathrm{Ph}^{[12]}$ Therefore, the preferred $\alpha$-arylation pathway when $\mathrm{Z}=\mathrm{SO}_{2} \mathrm{NMe}_{2}$ seems to be INTOB $\rightarrow$ INT1B $\rightarrow$ INT2B $\rightarrow$ INT3B $\rightarrow$ TS3B $\rightarrow$ 2MB. In this particular case, it can also be suggested that the nitrogen atom of the sulfonamide can coordinate the transition metal in the coordinatively unsaturated complex INT3B. However, although such coordination is strongly exergonic $\left(\Delta G_{R}=-11.3 \mathrm{kcal} / \mathrm{mol}\right)$, the corresponding reductive elimination reaction via TS3B' proceeds with a much higher activation barrier $\left(\Delta \mathrm{G}^{\neq}=28.7\right.$ $\mathrm{kcal} / \mathrm{mol})$ than the analogous process involving TS3B $\left(\Delta \mathrm{G}^{\neq}=\right.$ $15.9 \mathrm{kcal} / \mathrm{mol})$.

Finally, we investigated the reasons for the observed lower yields in the domino reactions involving methyl acrylate $(43 \%)$ or $\mathrm{N}, \mathrm{N}$-dibenzylethenesulfonamide $(25 \%)$ with respect to vinyl sulfones (ca. 70\%) as Michael acceptors (see Table 2). As shown in Figure 3, the computed activation barriers involving $Y=$ $\mathrm{CO}_{2} \mathrm{Me}\left(\Delta \mathrm{G}^{\neq}=19.7 \mathrm{kcal} / \mathrm{mol}\right)$ or $\mathrm{Y}=\mathrm{SO}_{2} \mathrm{NMe}_{2}\left(\Delta \mathrm{G}^{\neq}=21.6\right.$ $\mathrm{kcal} / \mathrm{mol})$ are clearly higher than that computed for the Michael addition reaction involving the vinyl sulfone $\left(\mathrm{Y}=\mathrm{SO}_{2} \mathrm{Ph}, \Delta \mathrm{G}^{\neq}=\right.$ $15.8 \mathrm{kcal} / \mathrm{mol})$. This can be ascribed to the relative electrophilicity of the Michael acceptor, which can be roughly estimated by the relative energy of the corresponding LUMO: $1.64 \mathrm{eV}\left(\mathrm{Y}=\mathrm{SO}_{2} \mathrm{Ph}\right)>-1.49 \mathrm{eV}\left(\mathrm{Y}=\mathrm{CO}_{2} \mathrm{Me}\right)>-1.11 \mathrm{eV}(\mathrm{Y}=$ $\mathrm{SO}_{2} \mathrm{NMe}_{2}$ ). Therefore, the experimentally observed reactivity trend is very likely related to the relative electrophililicity of the Michael acceptor used in the $\alpha$-arylation/Michael addition domino process.

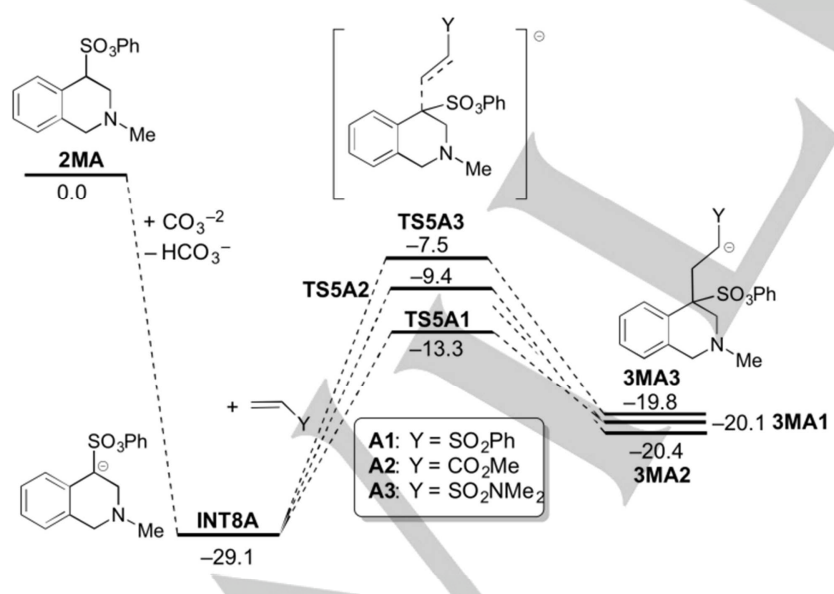

Figure 3. Computed reaction profiles for the Michael addition reaction involving 2MA and the different Michael acceptors. Relative free energies $(\Delta \mathrm{G}$, at $298 \mathrm{~K}$ ) are given in $\mathrm{kcal} / \mathrm{mol}$. All data were computed at the PCM(tetrahydrofuran)-B3LYP-D3/def2-TZVP//PCM(tetrahydrofuran)-B3LYPD3/def2-SVP level.

\section{Conclusions}

In summary, this joint experimental-computational comparative study has established the feasibility of using different nucleophiles and Michael acceptors in the domino $\alpha$ arylation/Michael addition process leading to tetrahydroisoquinolines. Our calculations indicate that two competing mechanisms, namely the direct base-mediated $\alpha$ arylation reaction and a concerted metalation-deprotonation (CMD) $\mathrm{C}-\mathrm{H}$ activation process, can be operative in the $\alpha$ arylation step of sulfonates and phosphonates when using $\mathrm{Cs}_{2} \mathrm{CO}_{3}$ as the base. In contrast, in the sulfonamide reaction, the base-mediated process seems to be preferred over the concerted metalation-deprotonation pathway. Our study also indicates that the success of the two-step domino process is strongly related to the electrophilicity of the Michael acceptor. Main Text Paragraph.

\section{Experimental Section}

General Remarks: All commercially available reagents were used without further purification. All nonaqueous reactions were carried out under an argon atmosphere. TLC was carried out on $\mathrm{SiO}_{2}$ (silica gel 60 $\mathrm{F}_{254}$, Merck), and the spots were located with UV light, $1 \%$ iodoplatinate reagent or $1 \%$ aqueous $\mathrm{KMnO}_{4}$. Flash chromatography was carried out on $\mathrm{SiO}_{2}$ (silica gel 60, SDS, 230-400 mesh ASTM). Drying of organic extracts during workup of reactions was performed over anhydrous $\mathrm{Na}_{2} \mathrm{SO}_{4}$. Solvents were evaporated with a rotatory evaporator. ${ }^{1} \mathrm{H}$ - and ${ }^{13} \mathrm{C}-\mathrm{NMR}$ spectra were recorded using $\mathrm{Me}_{4} \mathrm{Si}$ as the internal standard, with a Varian Mercury 400 instrument. Chemical shifts are reported in ppm downfield ( $\delta$ ) from $\mathrm{Me}_{4} \mathrm{Si}$ for ${ }^{1} \mathrm{H}$ - and ${ }^{13} \mathrm{C}$ - NMR. HRMS were obtained using a LC/MSD TOF mass spectrometer.

Typical Method for the Pd(0)-Catalyzed $\alpha$-Arylation Reaction (Table 1, Entry 4). A mixture of sulfonamide $1 \mathbf{b}(75 \mathrm{mg}, 0.123 \mathrm{mmol}), \mathrm{Pd}_{2}(\mathrm{dba})_{3}$ ( $8 \mathrm{mg}, 0.009 \mathrm{mmol})$, xantphos (11 $\mathrm{mg}, 0.018 \mathrm{mmol})$, and $\mathrm{Cs}_{2} \mathrm{CO}_{3}(120$ $\mathrm{mg}, 0.37 \mathrm{mmol})$ in THF $(8 \mathrm{~mL})$ was stirred at $120^{\circ} \mathrm{C}$ in a sealed tube for $72 \mathrm{~h}$. The reaction mixture was partitioned between saturated $\mathrm{NaHCO}_{3}$ aqueous solution and $\mathrm{Et}_{2} \mathrm{O}$. The organic extracts were dried and concentrated. The residue was purified by chromatography $\left(\mathrm{CH}_{2} \mathrm{Cl}_{2}\right)$ to give sulfonamide $\mathbf{2 b}$ ( $45 \mathrm{mg}, 75 \%$ ).

Phenyl 2-benzyl-1,2,3,4-tetrahydroisoquinoline-4-sulfonate (2a). Chromatography $\left(\mathrm{SiO}_{2}\right.$, from hexanes to $\left.\mathrm{CH}_{2} \mathrm{Cl}_{2}\right)$. Orange oil. ${ }^{1} \mathrm{H}$ NMR $\left(\mathrm{CDCl}_{3}, 400 \mathrm{MHz}\right) \delta 3.03(\mathrm{dd}, J=13.0$ and $4.2 \mathrm{~Hz}, 1 \mathrm{H}), 3.50(\mathrm{~d}, J=15.2$ $\mathrm{Hz}, 1 \mathrm{H}$ ), $3.71(\mathrm{~d}, J=12.8 \mathrm{~Hz}, 1 \mathrm{H}), 3.73$ (ddd, $J=13.0,4.2$ and $1.0 \mathrm{~Hz}$, $1 \mathrm{H}), 3.79(\mathrm{~d}, J=12.8 \mathrm{~Hz}, 1 \mathrm{H}), 3.94(\mathrm{~d}, J=15.2 \mathrm{~Hz}, 1 \mathrm{H}), 4.72(\mathrm{t}, J=4.2$ $\mathrm{Hz}, 1 \mathrm{H}), 6.99-7.02(\mathrm{~m}, 2 \mathrm{H}), 7.09(\mathrm{~d}, J=7.4 \mathrm{~Hz}, 1 \mathrm{H}), 7.19-7.34(\mathrm{~m}, 8 \mathrm{H})$, $7.40(\mathrm{~d}, 2 \mathrm{H}), 7.65(\mathrm{~d}, J=7.4 \mathrm{~Hz}, 1 \mathrm{H}),{ }^{13} \mathrm{C} \mathrm{NMR}\left(\mathrm{CDCl}_{3}, 100.6 \mathrm{MHz}\right) \delta$ $51.4\left(\mathrm{CH}_{2}\right), 55.2\left(\mathrm{CH}_{2}\right), 62.3(\mathrm{CH}), 62.3\left(\mathrm{CH}_{2}\right), 122.2(2 \mathrm{CH}), 125.4(\mathrm{C})$, $126.8(\mathrm{CH}), 126.9(\mathrm{CH}), 127.3(\mathrm{CH}), 127.5(\mathrm{CH}), 128.5(2 \mathrm{CH}), 129.0$ $(\mathrm{CH}), 129.2(2 \mathrm{CH}), 129.7(2 \mathrm{CH}), 130.5(\mathrm{CH}), 137.1(\mathrm{C}), 137.4(\mathrm{C})$, 149.3 (C). HRMS (ESI-TOF) calcd. for $\mathrm{C}_{22} \mathrm{H}_{22} \mathrm{NO}_{3} \mathrm{~S}: 380.1315[\mathrm{M}+\mathrm{H}]^{+}$; found: 380.1324 .

N,N,2-Tribenzyl-1,2,3,4-tetrahydroisoquinoline-4-sulfonamide (2b). Chromatography $\left(\mathrm{SiO}_{2}\right.$, from $\mathrm{CH}_{2} \mathrm{Cl}_{2}$ to $\left.\mathrm{CH}_{2} \mathrm{Cl}_{2}-\mathrm{MeOH} 1 \%\right)$. Brown oil. ${ }^{1} \mathrm{H}$ $\operatorname{NMR}\left(\mathrm{CDCl}_{3}, 400 \mathrm{MHz}\right) \delta 2.78$ (dd, $J=12.8$ and $\left.4.4 \mathrm{~Hz}, 1 \mathrm{H}\right), 3.37(\mathrm{~d}, J=$ $15.2 \mathrm{~Hz}, 1 \mathrm{H}$ ), 3.57 (d, $J=12.8 \mathrm{~Hz}, 1 \mathrm{H}), 3.69(\mathrm{dd}, J=12.8$ and $2.4 \mathrm{~Hz}, 1 \mathrm{H})$, 3.78 (d, $J=12.8 \mathrm{~Hz}, 1 \mathrm{H}$ ), 3.90 (d, $J=15.2 \mathrm{~Hz}, 1 \mathrm{H}$ ), 4.12 (s, 4H), 4.50 (dd, 
$J=4.4$ and $2.4 \mathrm{~Hz}, 1 \mathrm{H}), 6.95-6.99(\mathrm{~m}, 4 \mathrm{H}), 7.06-7.31(\mathrm{~m}, 14 \mathrm{H}), 7.71(\mathrm{~d}, J$ $=7.6 \mathrm{~Hz}, 1 \mathrm{H}) \cdot{ }^{13} \mathrm{C} \mathrm{NMR}\left(\mathrm{CDCl}_{3}, 100.6 \mathrm{MHz}\right) \delta 52.1\left(\mathrm{CH}_{2}\right), 52.3\left(\mathrm{CH}_{2}\right)$, $55.2\left(\mathrm{CH}_{2}\right), 63.0\left(\mathrm{CH}_{2}\right), 64.9(\mathrm{CH}), 126.6(\mathrm{C}), 126.7(\mathrm{CH}), 127.1(\mathrm{CH})$, $127.4(\mathrm{CH}), 127.6(\mathrm{CH}), 128.2(\mathrm{CH}), 128.5(\mathrm{CH}), 128.6(\mathrm{CH}), 128.8(\mathrm{CH})$ $129.7(\mathrm{CH}), 130.8(\mathrm{CH}), 136.4(\mathrm{C}), 136.6(\mathrm{C}), 136.7(\mathrm{C})$. HRMS (ESITOF) calcd. for $\mathrm{C}_{30} \mathrm{H}_{31} \mathrm{~N}_{2} \mathrm{O}_{2} \mathrm{~S}: 483.2101[\mathrm{M}+\mathrm{H}]^{+}$; found: 483.2103

Diethyl 2-benzyl-1,2,3,4-tetrahydroisoquinolin-4-ylphosphonate (2c). Chromatography $\left(\mathrm{SiO}_{2}\right.$, from $\mathrm{CH}_{2} \mathrm{Cl}_{2}$ to $\mathrm{CH}_{2} \mathrm{Cl}_{2} / \mathrm{MeOH} 4 \%$ ). Yellow oil. ${ }^{1} \mathrm{H}$ $\operatorname{NMR}\left(\mathrm{CDCl}_{3}, 400 \mathrm{MHz}\right) \delta 1.16(\mathrm{t}, J=7.2 \mathrm{~Hz}, 3 \mathrm{H}), 1.18(\mathrm{t}, J=7.2 \mathrm{~Hz}, 3 \mathrm{H})$ 2.86 (ddd, $J=25.2,11.6$ and $4.8 \mathrm{~Hz}, 1 \mathrm{H}$ ), $3.29(\mathrm{td}, J=11.6$ and $4.8 \mathrm{~Hz}$, $1 \mathrm{H}), 3.42-3.51(\mathrm{~m}, 2 \mathrm{H}), 3.64(\mathrm{~d}, J=13.2 \mathrm{~Hz}, 1 \mathrm{H}), 3.73(\mathrm{dd}, J=15.2$ and $1.6 \mathrm{~Hz}, 1 \mathrm{H}), 3.76(\mathrm{~d}, J=13.2 \mathrm{~Hz}, 1 \mathrm{H}), 3.84-4.09(\mathrm{~m}, 4 \mathrm{H}), 6.98(\mathrm{~m}, 1 \mathrm{H})$, 7.11-7.19 (m, 2H), 7.24-7.41 (m, 5H), $7.54(\mathrm{~m}, 1 \mathrm{H}) .{ }^{13} \mathrm{C} \mathrm{NMR}\left(\mathrm{CDCl}_{3}\right.$, $100.5 \mathrm{MHz}) \delta 16.4$ (d, J $\left.J_{\mathrm{C}-\mathrm{P}}=6.1 \mathrm{~Hz}, \mathrm{CH}_{3}\right), 16.5\left(\mathrm{~d}, \mathrm{~J}_{\mathrm{C}-\mathrm{P}}=4.5 \mathrm{~Hz}, \mathrm{CH}_{3}\right)$, 38.9 (d, J $\left.J_{\text {C-P }}=137.9 \mathrm{~Hz}, \mathrm{CH}\right), 51.6\left(\mathrm{~d}, J_{\mathrm{C}-\mathrm{P}}=4.6 \mathrm{~Hz}, \mathrm{CH}_{2}\right), 55.7$ (d, J-P $=$ $1.5 \mathrm{~Hz}, \mathrm{CH}_{2}$ ), 62.1 (d, JC-P $=6.1 \mathrm{~Hz}, \mathrm{CH}_{2}$ ), $62.2\left(\mathrm{~d}, \mathrm{~J}_{\mathrm{C}-\mathrm{P}}=6.9 \mathrm{~Hz}, \mathrm{CH}_{2}\right.$ ), $62.8\left(\mathrm{CH}_{2}\right), 126.3$ (d, J $\left.J_{\mathrm{C}-\mathrm{P}}=3.0 \mathrm{~Hz}, \mathrm{CH}\right), 126.7$ (d, J $J_{\mathrm{C}-\mathrm{P}}=3.0 \mathrm{~Hz}, \mathrm{CH}_{2}$ ), $126.9\left(\mathrm{~d}, \mathrm{~J}_{\mathrm{C}-\mathrm{P}}=2.3 \mathrm{~Hz}, \mathrm{CH}_{2}\right), 127.3(\mathrm{~s}, \mathrm{CH}), 128.3(\mathrm{~s}, 2 \mathrm{CH}), 129.4(\mathrm{~s}, 2$ $\mathrm{CH}), 129.6$ (s, C), 129.7 (d, J $\left.J_{\mathrm{C}-\mathrm{P}}=4.6 \mathrm{~Hz}, \mathrm{CH}\right), 135.5$ (d, J $\mathrm{J}_{\mathrm{C}-\mathrm{P}}=6.9 \mathrm{~Hz}, \mathrm{C}$ ) 138.0 (s, C). HRMS (ESI-TOF) calcd. for $\mathrm{C}_{20} \mathrm{H}_{27} \mathrm{NO}_{3} \mathrm{P}: 360.1723[\mathrm{M}+\mathrm{H}]^{+}$ found: 360.1724

Typical Method for the Domino Reactions (Table 2, Entry 1). A mixture of sulfonate 1a $(75 \mathrm{mg}, 0.148 \mathrm{mmol}), \mathrm{Pd}\left(\mathrm{PPh}_{3}\right)_{4}(17 \mathrm{mg}, 0.015$ $\mathrm{mmol})$, xantphos $(8.5 \mathrm{mg}, 0.015 \mathrm{mmol})$, phenyl vinyl sulfone $(37 \mathrm{mg}, 0.22$ $\mathrm{mmol}$ ), and $\mathrm{K}_{3} \mathrm{PO}_{4}(94 \mathrm{mg}, 0.44 \mathrm{mmol})$ in THF $(8 \mathrm{~mL})$ was stirred at 120 ${ }^{\circ} \mathrm{C}$ in a sealed tube for $72 \mathrm{~h}$. The reaction mixture was poured into water and extracted with $\mathrm{Et}_{2} \mathrm{O}$. The organic extracts were washed with brine, dried, and concentrated. The residue was purified by flash chromatography $\left(\mathrm{SiO}_{2}\right.$, from $\mathrm{CH}_{2} \mathrm{Cl}_{2}$ to $\left.\mathrm{CH}_{2} \mathrm{Cl}_{2}-\mathrm{MeOH} 1 \%\right)$ to give sulfonate 3aa (55 mg, 68\%)

\section{Phenyl 2-benzyl-4-[2-(phenylsulfonyl)ethyl]-1,2,3,4} tetrahydroisoquinoline-4-sulfonate (3aa). Yellow foam. ${ }^{1} \mathrm{H}$ NMR $\left(\mathrm{CDCl}_{3}, 400 \mathrm{MHz}\right) \delta 2.62(\mathrm{td}, \mathrm{J}=13.6$ and $4.4 \mathrm{~Hz}, 1 \mathrm{H}), 2.80-2.91(\mathrm{~m}, 2 \mathrm{H})$ $3.13(\mathrm{dd}, J=12.4$ and $2.0 \mathrm{~Hz}, 1 \mathrm{H}$ ), $3.26(\mathrm{~d}, J=12.4 \mathrm{~Hz}, 1 \mathrm{H}$ ), 3.50 (ddd, $J$ $=14.4,13.2$ and $4.4 \mathrm{~Hz}, 1 \mathrm{H}), 3.53(\mathrm{~d}, J=15.6 \mathrm{~Hz}, 1 \mathrm{H}), 3.60(\mathrm{~d}, J=12.8$ $\mathrm{Hz}, 1 \mathrm{H}), 3.73(\mathrm{~d}, J=15.6 \mathrm{~Hz}, 1 \mathrm{H}), 3.74(\mathrm{~d}, J=12.8 \mathrm{~Hz}, 1 \mathrm{H}), 6.79(\mathrm{~m}, 2 \mathrm{H})$ $7.09(\mathrm{~d}, J=7.6 \mathrm{~Hz}, 1 \mathrm{H}), 7.13-7.38(\mathrm{~m}, 10 \mathrm{H}), 7.51-7.59(\mathrm{~m}, 3 \mathrm{H}), 7.66(\mathrm{tt}, J$ $=7.6$ and $1.2 \mathrm{~Hz}, 1 \mathrm{H}), 7.79(\mathrm{~m}, 2 \mathrm{H}) .{ }^{13} \mathrm{C} \mathrm{NMR}\left(\mathrm{CDCl}_{3}, 100.5 \mathrm{MHz}\right) \delta 31.2$ $\left(\mathrm{CH}_{2}\right), 52.1\left(\mathrm{CH}_{2}\right), 56.6\left(\mathrm{CH}_{2}\right), 57.0\left(\mathrm{CH}_{2}\right), 62.7\left(\mathrm{CH}_{2}\right), 68.1(\mathrm{C}), 121.9$ $\mathrm{CH}), 127.0(\mathrm{CH}), 127.4(\mathrm{CH}), 127.6(\mathrm{CH}), 127.9(\mathrm{CH}), 128.0(\mathrm{CH}), 128$. (C), $128.2(2 \mathrm{CH}), 128.8(2 \mathrm{CH}), 129.1(\mathrm{CH}), 129.4(2 \mathrm{CH}), 129.5(2 \mathrm{CH})$, $129.7(2 \mathrm{CH}), 134.0(\mathrm{CH}), 136.9(\mathrm{C}), 137.3(\mathrm{C}), 138.6(\mathrm{C}), 149.1(\mathrm{C})$ HRMS (ESI-TOF) cald for $\mathrm{C}_{30} \mathrm{H}_{30} \mathrm{NO}_{5} \mathrm{~S}_{2}: 548.1560[\mathrm{M}+\mathrm{H}]^{+}$; found: 548.1567 .

\section{Phenyl \\ 2-benzyl-4-[2-(methylsulfonyl)ethyl]-1,2,3,4- tetrahydroisoquinoline-4-sulfonate (3ab). Yellow Oil. ${ }^{1} \mathrm{H} \mathrm{NMR}\left(\mathrm{CDCl}_{3}\right.$, $400 \mathrm{MHz}) \delta$ 2.67-2.78 (m, 2H), $2.75(\mathrm{~s}, 3 \mathrm{H}), 2.90-3.01(\mathrm{~m}, 1 \mathrm{H}), 3.22$ (dd, $J=12.4$ and $1.6 \mathrm{~Hz}, 1 \mathrm{H}), 3.27(\mathrm{~d}, J=12.4 \mathrm{~Hz}, 1 \mathrm{H}), 3.37-3.47(\mathrm{~m}, 1 \mathrm{H})$, $3.60(\mathrm{~d}, J=12.8 \mathrm{~Hz}, 1 \mathrm{H}), 3.61(\mathrm{~d}, J=14.8 \mathrm{~Hz}, 1 \mathrm{H}), 3.82(\mathrm{~d}, J=12.8 \mathrm{~Hz}$, $1 \mathrm{H}), 3.83(\mathrm{~d}, J=14.8 \mathrm{~Hz}, 1 \mathrm{H}), 6.85(\mathrm{~m}, 2 \mathrm{H}), 7.14(\mathrm{dd}, J=8.0$ and $1.2 \mathrm{~Hz}$, $1 \mathrm{H}), 7.18-7.40(\mathrm{~m}, 10 \mathrm{H}), 7.79(\mathrm{dd}, \mathrm{J}=8.0$ and $1.2 \mathrm{~Hz}, 1 \mathrm{H}) .{ }^{13} \mathrm{C} \mathrm{NMR}$ $\left(\mathrm{CDCl}_{3}, 100.5 \mathrm{MHz}\right) \delta 31.1\left(\mathrm{CH}_{2}\right), 40.5\left(\mathrm{CH}_{3}\right), 50.7\left(\mathrm{CH}_{2}\right), 56.5\left(\mathrm{CH}_{2}\right)$, $56.9\left(\mathrm{CH}_{2}\right), 62.6\left(\mathrm{CH}_{2}\right), 68.1(\mathrm{C}), 122.0(2 \mathrm{CH}), 127.1(\mathrm{CH}), 127.5(\mathrm{CH})$, $127.7(\mathrm{CH}), 128.0(\mathrm{CH}), 128.1(\mathrm{CH}), 128.5(\mathrm{C}), 128.9(2 \mathrm{CH}), 129.2(\mathrm{CH})$ 129.6 (2 CH), 129.8 (2 CH), 137.0 (C), 137.2 (C), 149.1 (C). HRMS (ESI- TOF) cald for $\mathrm{C}_{25} \mathrm{H}_{28} \mathrm{NO}_{5} \mathrm{~S}_{2}: 486.1403[\mathrm{M}+\mathrm{H}]^{+}$; found: 486.1403 .}

$J=11.2,8.0$ and $5.2 \mathrm{~Hz}, 1 \mathrm{H}$ ), 2.69 (ddd, $J=11.2,8.0$ and $5.2 \mathrm{~Hz}, 1 \mathrm{H}$ ), 2.84 (ddd, $J=16.2,11.2$ and $5.2 \mathrm{~Hz}, 1 \mathrm{H}$ ), 3.18 (dd, $J=12.4$ and $1.6 \mathrm{~Hz}$, $1 \mathrm{H}), 3.38(\mathrm{~d}, J=12.4 \mathrm{~Hz}, 1 \mathrm{H}), 3.58(\mathrm{~d}, J=14.8 \mathrm{~Hz}, 1 \mathrm{H}), 3.63(\mathrm{~s}, 3 \mathrm{H})$ $3.69(\mathrm{~d}, J=13.2 \mathrm{~Hz}, 1 \mathrm{H}), 3.70(\mathrm{~d}, J=14.8 \mathrm{~Hz}, 0031 \mathrm{H}), 3.74(\mathrm{~d}, J=13.2$ $\mathrm{Hz}, 1 \mathrm{H}), 6.84(\mathrm{~m}, 2 \mathrm{H}), 7.08(\mathrm{dd}, J=7.6$ and $1.2 \mathrm{~Hz}, 1 \mathrm{H}), 7.16-7.38(\mathrm{~m}$, $10 \mathrm{H}), 7.77$ (dd, $J=7.6$ and $1.2 \mathrm{~Hz}, 1 \mathrm{H}) .{ }^{13} \mathrm{C} \mathrm{NMR}\left(\mathrm{CDCl}_{3}, 100.5 \mathrm{MHz}\right) \delta$ $29.7\left(\mathrm{CH}_{2}\right), 32.5\left(\mathrm{CH}_{2}\right), 51.9\left(\mathrm{CH}_{3}\right), 56.3\left(\mathrm{CH}_{2}\right), 57.0\left(\mathrm{CH}_{2}\right), 62.6\left(\mathrm{CH}_{2}\right)$, $69.2(\mathrm{C}), 122.1(2 \mathrm{CH}), 126.8(\mathrm{CH}), 127.2(\mathrm{CH}), 127.3(\mathrm{CH}), 127.7(\mathrm{CH})$, $128.4(\mathrm{CH}), 128.6(2 \mathrm{CH}), 128.7(\mathrm{CH}), 129.1(\mathrm{C}), 129.2(2 \mathrm{CH}), 129.6(2$ $\mathrm{CH}), 137.2(\mathrm{C}), 137.3(\mathrm{C}), 149.3(\mathrm{C}) .173 .0(\mathrm{C})$. HRMS (ESI-TOF) cald for $\mathrm{C}_{26} \mathrm{H}_{28} \mathrm{NO}_{5} \mathrm{~S}: 466.1683[\mathrm{M}+\mathrm{H}]^{+}$; found: 466.1683

Phenyl 2-benzyl-4-[2-(phenoxysulfonyl)ethyl]-1,2,3,4tetrahydroisoquinoline-4-sulfonate (3ad). Yellow foam. ${ }^{1} \mathrm{H}$ NMR $\left(\mathrm{CDCl}_{3}, 400 \mathrm{MHz}\right) \delta 2.93(\mathrm{td}, \mathrm{J}=12.4$ and $3.2 \mathrm{~Hz}, 1 \mathrm{H}), 2.99$ (td, $\mathrm{J}=12.4$ and $3.2 \mathrm{~Hz}, 1 \mathrm{H}), 3.11$ (td, $J=12.4$ and $3.2 \mathrm{~Hz}, 1 \mathrm{H}), 3.27(\mathrm{~s}, 2 \mathrm{H}), 3.56(\mathrm{~d}$, $J=15.2 \mathrm{~Hz}, 1 \mathrm{H}), 3.63(\mathrm{~d}, J=12.8 \mathrm{~Hz}, 1 \mathrm{H}), 3.72(\mathrm{td}, J=12.4$ and $3.2 \mathrm{~Hz}$, $1 \mathrm{H}), 3.78(\mathrm{~d}, J=12.8 \mathrm{~Hz}, 1 \mathrm{H}), 3.82(\mathrm{~d}, J=15.2 \mathrm{~Hz}, 1 \mathrm{H}), 6.87(\mathrm{~m}, 2 \mathrm{H})$, $7.13(\mathrm{dd}, J=7.6$ and $0.8 \mathrm{~Hz}, 1 \mathrm{H}), 7.17-7.38(\mathrm{~m}, 15 \mathrm{H}), 7.82(\mathrm{dd}, J=8.0$ and $1.2 \mathrm{~Hz}, 1 \mathrm{H}) .{ }^{13} \mathrm{C} \mathrm{NMR}\left(\mathrm{CDCl}_{3}, 100.5 \mathrm{MHz}\right) \delta 32.3\left(\mathrm{CH}_{2}\right), 46.7\left(\mathrm{CH}_{2}\right)$, $56.6\left(\mathrm{CH}_{2}\right), 56.8\left(\mathrm{CH}_{2}\right), 62.6\left(\mathrm{CH}_{2}\right), 68.0(\mathrm{C}), 122.0(2 \mathrm{CH}), 122.1(2 \mathrm{CH})$, $127.1(\mathrm{CH}), 127.4(\mathrm{CH}), 127.6(\mathrm{CH}), 127.7(\mathrm{CH}), 128.0(\mathrm{CH}), 128.1(\mathrm{CH})$, $128.3(\mathrm{C}), 128.9(2 \mathrm{CH}), 129.2(\mathrm{CH}), 129.3(2 \mathrm{CH}), 129.8(2 \mathrm{CH}), 130.1$ (2 CH), 136.7 (C), $137.1(\mathrm{C}), 149.0$ (C), 149.1 (C). HRMS (ESI-TOF) cald for $\mathrm{C}_{30} \mathrm{H}_{30} \mathrm{NO}_{6} \mathrm{~S}_{2}: 564.1509[\mathrm{M}+\mathrm{H}]^{+}$; found: 564.1518 .

Phenyl 2-benzyl-4-[2-( $N, N$-dibenzylaminosulfonyl)ethyl]-1,2,3,4-

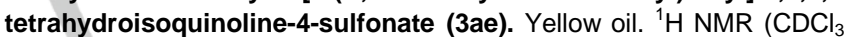
$400 \mathrm{MHz}) \delta 2.68-2.79(\mathrm{~m}, 2 \mathrm{H}), 2.88-2.99(\mathrm{~m}, 1 \mathrm{H}), 3.07(\mathrm{dd}, J=12.4$ and $1.2 \mathrm{~Hz}, 1 \mathrm{H}), 3.26(\mathrm{~d}, J=12.4 \mathrm{~Hz}, 1 \mathrm{H}), 3.20-3.33(\mathrm{~m}, 1 \mathrm{H}), 3.54(\mathrm{~d}, J=$ $14.8 \mathrm{~Hz}, 1 \mathrm{H}), 3.61(\mathrm{~d}, J=13.2 \mathrm{~Hz}, 1 \mathrm{H}), 3.69(\mathrm{~d}, J=14.8 \mathrm{~Hz}, 1 \mathrm{H}), 3.71(\mathrm{~d}$, $J=13.2 \mathrm{~Hz}, 1 \mathrm{H}), 4.22(\mathrm{~d}, J=15.2 \mathrm{~Hz}, 2 \mathrm{H}), 4.30(\mathrm{~d}, J=15.2 \mathrm{~Hz}, 2 \mathrm{H})$, $6.85(\mathrm{~m}, 2 \mathrm{H}), 7.09(\mathrm{dd}, J=7.6$ and $1.2 \mathrm{~Hz}, 1 \mathrm{H}), 7.17-7.35(\mathrm{~m}, 20 \mathrm{H}), 7.71$ $(\mathrm{dd}, J=8.0$ and $0.8 \mathrm{~Hz}, 1 \mathrm{H}) .{ }^{13} \mathrm{C} \mathrm{NMR}\left(\mathrm{CDCl}_{3}, 100.5 \mathrm{MHz}\right) \delta 31.7\left(\mathrm{CH}_{2}\right)$, $49.7\left(\mathrm{CH}_{2}\right), 50.3\left(2 \mathrm{CH}_{2}\right), 56.5\left(\mathrm{CH}_{2}\right), 57.0\left(\mathrm{CH}_{2}\right), 62.6\left(\mathrm{CH}_{2}\right), 68.4(\mathrm{C})$, $122.0(2 \mathrm{CH}), 127.0(\mathrm{CH}), 127.4(\mathrm{CH}), 127.5(\mathrm{CH}), 127.8(\mathrm{CH}), 128.1(2$ $\mathrm{CH}), 128.3(\mathrm{CH}), 128.4(\mathrm{C}), 128.7(2 \mathrm{CH}), 128.8(4 \mathrm{CH}), 128.9(4 \mathrm{CH})$, $129.0(\mathrm{CH}), 129.2(2 \mathrm{CH}), 129.7(2 \mathrm{CH}), 135.7(2 \mathrm{C}), 137.0(\mathrm{C}), 137.2(\mathrm{C})$, 149.2 (C). HRMS (ESI-TOF) cald for $\mathrm{C}_{38} \mathrm{H}_{39} \mathrm{~N}_{2} \mathrm{O}_{5} \mathrm{~S}_{2}: 667.2295[\mathrm{M}+\mathrm{H}]^{+}$; found: 667.2289

\section{2,N,N-Tribenzyl-4-[2-(phenylsulfonyl)ethyl]-1,2,3,4-}

tetrahydroisoquinoline-4-sulfonamide (3ba). Yellow oil. ${ }^{1} \mathrm{H}$ NMR $\left(\mathrm{CDCl}_{3}, 400 \mathrm{MHz}\right) \delta 2.63$ (ddd, $J=13.6,12.8$ and $4.8 \mathrm{~Hz}, 1 \mathrm{H}$ ), 2.79 (ddd, $J=13.6,12.8$ and $3.6 \mathrm{~Hz}, 1 \mathrm{H}), 2.86(\mathrm{~d}, J=12.4 \mathrm{~Hz}, 1 \mathrm{H}), 2.89$ (ddd, $J=$ 13.6, 12.8 and $3.6 \mathrm{~Hz}, 1 \mathrm{H}), 3.16(\mathrm{~d}, J=12.4 \mathrm{~Hz}, 1 \mathrm{H}), 3.44(\mathrm{~d}, J=12.8$ $\mathrm{Hz}, 1 \mathrm{H}$ ), 3.49 (ddd, $J=13.6,12.8$ and $4.8 \mathrm{~Hz}, 1 \mathrm{H}), 3.49(\mathrm{~d}, J=14.8 \mathrm{~Hz}$, $1 \mathrm{H}), 3.57$ (d, $J=14.8 \mathrm{~Hz}, 1 \mathrm{H}), 3.70(\mathrm{~d}, J=12.8 \mathrm{~Hz}, 1 \mathrm{H}), 4.01$ (broad s, $4 \mathrm{H}), 6.77(\mathrm{~d}, J=6.8 \mathrm{~Hz}, 4 \mathrm{H}), 7.06-7.35(\mathrm{~m}, 14 \mathrm{H}), 7.55$ (tt, $J=7.6$ and 1.2 $\mathrm{Hz}, 2 \mathrm{H}), 7.65$ (tt, $J=7.6$ and $1.2 \mathrm{~Hz}, 1 \mathrm{H}), 7.76(\mathrm{dd}, J=8.0$ and $1.2 \mathrm{~Hz}$, $1 \mathrm{H}), 7.83(\mathrm{~m}, 2 \mathrm{H}) .{ }^{13} \mathrm{C} \mathrm{NMR}\left(\mathrm{CDCl}_{3}, 100.5 \mathrm{MHz}\right) \delta 31.6\left(\mathrm{CH}_{2}\right), 52.4\left(\mathrm{CH}_{2}\right)$, $52.5\left(2 \mathrm{CH}_{2}\right), 56.4\left(\mathrm{CH}_{2}\right), 57.1\left(\mathrm{CH}_{2}\right), 63.0\left(\mathrm{CH}_{2}\right), 69.7(\mathrm{C}), 127.4(\mathrm{CH})$, $127.5(\mathrm{CH}), 127.6(2 \mathrm{CH}), 127.9(\mathrm{CH}), 128.2(2 \mathrm{CH}), 128.3(4 \mathrm{CH}), 128.5$ $(4 \mathrm{CH}), 128.6(\mathrm{CH}), 128.8(2 \mathrm{CH}), 128.9(\mathrm{CH}), 129.5(2 \mathrm{CH}), 129.6(\mathrm{C})$, 129.7 (2 CH), $133.9(\mathrm{CH}), 135.7$ (2 C), $136.5(\mathrm{C}), 137.2(\mathrm{C}), 138.7(\mathrm{C})$. HRMS (ESI-TOF) cald for $\mathrm{C}_{38} \mathrm{H}_{39} \mathrm{~N}_{2} \mathrm{O}_{4} \mathrm{~S}_{2}: 651.2346[\mathrm{M}+\mathrm{H}]^{+}$; found: 651.2349 .

\section{2,N,N-Tribenzyl-4-[2-(methylsulfonyl)ethyl]-1,2,3,4-}

tetrahydroisoquinoline-4-sulfonamide $\mathbf{( 3 b b )}$. Yellow oil. ${ }^{1} \mathrm{H}$ NMR $\left(\mathrm{CDCl}_{3}, 400 \mathrm{MHz}\right) \delta 2.73-2.91(\mathrm{~m}, 3 \mathrm{H}), 2.81$ (s, 3H), 2.94 (dd, $J=12.4$ and $1.2 \mathrm{~Hz}, 1 \mathrm{H}), 3.18(\mathrm{~d}, J=12.4 \mathrm{~Hz}, 1 \mathrm{H}), 3.42-3.51(\mathrm{~m}, 1 \mathrm{H}), 3.45(\mathrm{~d}, J=$ $12.8 \mathrm{~Hz}, 1 \mathrm{H}), 3.55(\mathrm{~d}, J=14.8 \mathrm{~Hz}, 1 \mathrm{H}), 3.66(\mathrm{~d}, J=14.8 \mathrm{~Hz}, 1 \mathrm{H}), 3.77(\mathrm{~d}$, $J=12.8 \mathrm{~Hz}, 1 \mathrm{H}$ ), 4.08 (broad s, 4H), $6.80(\mathrm{~d}, J=6.4 \mathrm{~Hz}, 4 \mathrm{H}), 7.09-7.17$ 
$(\mathrm{m}, 7 \mathrm{H}), 7.24-7.36(\mathrm{~m}, 7 \mathrm{H}), 7.99(\mathrm{dd}, J=7.6$ and $1.6 \mathrm{~Hz}, 1 \mathrm{H}) .{ }^{13} \mathrm{C}$ NMR $\left(\mathrm{CDCl}_{3}, 100.5 \mathrm{MHz}\right) \delta 31.7\left(\mathrm{CH}_{2}\right), 40.4\left(\mathrm{CH}_{3}\right), 50.9\left(\mathrm{CH}_{2}\right), 52.4\left(2 \mathrm{CH}_{2}\right)$, $56.6\left(2 \mathrm{CH}_{2}\right), 62.9\left(\mathrm{CH}_{2}\right), 69.7(\mathrm{C}), 127.4(\mathrm{CH}), 127.5(\mathrm{CH}), 127.6(2 \mathrm{CH})$, $127.9(\mathrm{CH}), 128.3(4 \mathrm{CH}), 128.5(4 \mathrm{CH}), 128.6(\mathrm{CH}), 128.8(2 \mathrm{CH}), 129.0$ $(\mathrm{CH}), 129.7(2 \mathrm{CH}), 130.0(\mathrm{C}), 135.7(2 \mathrm{C}), 136.5(\mathrm{C}), 137.1(\mathrm{C}) . \mathrm{HRMS}$ (ESI-TOF) cald for $\mathrm{C}_{33} \mathrm{H}_{3} \mathrm{~N}_{2} \mathrm{O}_{4} \mathrm{~S}_{2}: 589.2189[\mathrm{M}+\mathrm{H}]^{+}$; found: 589.2199 .

\section{Computational Details}

All the calculations reported in this paper were obtained with the GAUSSIAN 09 suite of programs. ${ }^{[13]}$ Electron correlation was partially taken into account using the hybrid functional usually denoted as B3LYP ${ }^{[14]}$ in conjunction with the D3 dispersion correction suggested by Grimme and co-workers ${ }^{[15]}$ using the double- $\zeta$ quality plus polarization def2-SVP basis set ${ }^{[16]}$ for all atoms. Reactants and products were characterized by frequency calculations, ${ }^{[17]}$ and have positive definite Hessian matrices. Transition structures (TS's) show only one negative eigenvalue in their diagonalized force constant matrices, and their associated eigenvectors were confirmed to correspond to the motion along the reaction coordinate under consideration using the Intrinsic Reaction Coordinate (IRC) method. ${ }^{[18]}$ Solvents effects were taken into account using the Polarizable Continuum Model (PCM) ${ }^{[19]}$ Single point calculations on the PCM(THF)-B3LYP-D3/def2-SVP geometries were performed to estimate the change in the Gibbs energies at the B3LYP-D3 level using the triple- $\zeta$ quality plus polarization def2-TZVP basis set ${ }^{[16]}$ for all atoms. This level is denoted PCM(THF)-B3LYP-D3/def2TZVP//PCM(THF)-B3LYP-D3/def2-SVP.

\section{Acknowledgements}

We gratefully acknowledge financial support for this work from the MINECO-FEDER (CTQ2013-44303-P, CTQ2015-64937-R, and CTQ2014-51912-REDC). Y.G.-R. acknowledges the MINECO for a FPI grant.

Keywords: arylation - palladium-catalyzed $\cdot$ Domino reactions • Nitrogen heterocycles $\bullet$ density functional calculations

[1] For selected reviews, see: a) Y. Hayashi, Chem. Sci. 2016, 7, 866-880; b) A. Dhakshinamoorthy, H. García, ChemSusChem 2014, 7, 2392 2410; c) A. Behr, A. J. Vorholt, K. A. Ostrowski, T. Seidensticker, Green Chem. 2014, 16, 982-1006; d) C. M. R. Volla, J. Atodiresei, M. Rueping Chem. Rev. 2014, 114, 2390-2431; e) D. M. D'Souza, T. J. J. Mueller Chem. Soc. Rev. 2007, 36, 1095-1108; f) K. C. Nicolaou, D. J. Edmons, P. G. Bulger, Angew. Chem. Int. Ed. 2006, 45, 7134-7186.

[2] L. F. Tietze, Chem. Rev. 1996, 96, 115-136.

[3] See, for example: a) R. Ferraccioli, D. Carenzi, M. Catellani, Tetrahedron Lett. 2004, 45, 6903-6907; b) M. W. Khan, A. F. G. M. Reza, Tetrahedron 2005, 61, 11204-11210; c) A. Rolfe, K. Young, P. R Hanson, Eur. J. Org. Chem. 2008, 5254-5262; d) D. L. Priebbenow, L. C. Henderson, F. M. Pfeffer, S. G. Stewart, J. Org. Chem. 2010, 75 1787-1790; e) D. L. Priebbenow, S. G. Stewart, F. M. Pfeffer, Org. Biomol. Chem., 2011, 9, 1508-1515; f) D. L. Priebbenow, F. M. Pfeffer, S. G. Stewart, Eur. J. Org. Chem. 2011, 1632-1635; g) K. Chen, S. A. Pullarkat, Org. Biomol. Chem., 2012, 10, 6600-6606; h) Q. Zang, S. Javed, P. Porubsky, F. Ullah, B. Neuenswander, G. H. Lushington, F. Z. Basha, M. G. Organ, P. R. Hanson, ACS Combi. Sci. 2012, 14, 211 217
[4] D. Solé, F. Pérez-Janer, R. Mancuso, Chem. Eur. J. 2015, 21, 45804584.

[5] D. Solé, F. Pérez-Janer, E. Zulaica, J. F. Guastavino, I. Fernández, ACS Catal. 2016, 6, 1691-1700.

[6] For the intermolecular Pd-catalyzed $\alpha$-arylation of sulfonamides, see: a) G. Zhou, P. Ting, R. Aslanian, J. Piwinski, Org. Lett. 2008, 10, 2517 2520; b) O. René, B. P. Fauber, S. Malhotra, H. Yajima, Org. Lett. 2014, 16, 3468-3471; c) B. Zheng, M. Li, G. Gao, Y. He, P. J. Walsh, Adv. Synth. Catal. 2016, 358, 2156-2162.

[7] For the intermolecular Pd-catalyzed $\alpha$-arylation of phosphonates, see: S. Montel, L. Raffier, Y. He, P. J. Walsh, Org. Lett. 2014, 16, 1446-1449.

[8] For reviews, see: a) D. A. Culkin, J. F. Hartwig, Acc. Chem. Res. 2003, 36, 234-245; b) F. Bellina, R. Rossi, Chem. Rev. 2010, 110, 1082-1146; c) C. C. C. Johansson, T. J. Colacot, Angew. Chem. Int. Ed. 2010, 49, 676-707; d) S. T. Sivanandan, A. Shaji, I. Ibnusaud, C. C. C. Johansson-Seechurn, T. J. Colacot, Eur. J. Org. Chem. 2015, 38-49.

[9] The tetrahydroisoquinoline framework is a common structural motif in pharmaceuticals and natural products. For recent reviews, see: a) K. W. Bentley, Nat. Prod. Rep., 2006, 23, 444-463; b) P. Siengalewicz, U. Rinner, J. Mulzer, Chem. Soc. Rev., 2008, 37, 2676-2690; c) K. Bhadra, G. S. Kumar, Mini-Reviews in Medicinal Chemistry, 2010, 10, 12351247; d) A. L. Souto, J. F. Tavares, M. Sobral da Silva, M. F. F. M. Diniz, P. Filgueiras de Athayde-Filho, J. M. Barbosa-Filho, Molecules, 2011, 16, 8515-8534; e) P. E. Alford, Progress in Heterocyclic Chemistry 2011, 23, 329-370.

[10] See Computational Details.

[11] For related processes, see: a) D. Solé, F. Mariani, I. Fernández, M. A. Sierra, J. Org. Chem. 2012, 77, 10272-10284; b) D. Solé, I. Fernández, Acc. Chem. Res. 2014, 47, 168-179, and references therein.

[12] For instance, a value of $\mathrm{pKa}=24.1$ (in DMSO) was measured for $\mathrm{Ph}-$ $\mathrm{CH}_{2}-\mathrm{SO}_{2} \mathrm{~N}(\mathrm{Ph}) \mathrm{Me}$ whereas a lower value of $\mathrm{pKa}=19.9$ was measured for $\mathrm{Ph}-\mathrm{CH}_{2}-\mathrm{SO}_{3} \mathrm{Ph}$. See: F. G. Bordwell, J. A. Harrelson, X. Zhang, J. Org. Chem. 1991, 56, 4448.

[13] Gaussian 09, Revision D.01, M. J. Frisch, G. W. Trucks, H. B. Schlegel, G. E. Scuseria, M. A. Robb, J. R. Cheeseman, G. Scalmani, V. Barone, B. Mennucci, G. A. Petersson, H. Nakatsuji, M. Caricato, X. Li, H. P. Hratchian, A. F. Izmaylov, J. Bloino, G. Zheng, J. L. Sonnenberg, M. Hada, M. Ehara, K. Toyota, R. Fukuda, J. Hasegawa, M. Ishida, T. Nakajima, Y. Honda, O. Kitao, H. Nakai, T. Vreven, J. A. Montgomery, Jr., J. E. Peralta, F. Ogliaro, M. Bearpark, J. J. Heyd, E. Brothers, K. N. Kudin, V. N. Staroverov, R. Kobayashi, J. Normand, K. Raghavachari, A. Rendell, J. C. Burant, S. S. lyengar, J. Tomasi, M. Cossi, N. Rega, J. M. Millam, M. Klene, J. E. Knox, J. B. Cross, V. Bakken, C. Adamo, J. Jaramillo, R. Gomperts, R. E. Stratmann, O. Yazyev, A. J. Austin, R. Cammi, C. Pomelli, J. W. Ochterski, R. L. Martin, K. Morokuma, V. G. Zakrzewski, G. A. Voth, P. Salvador, J. J. Dannenberg, S. Dapprich, A. D. Daniels, Ö. Farkas, J. B. Foresman, J. V. Ortiz, J. Cioslowski, and D. J. Fox, Gaussian, Inc., Wallingford CT, 2009.

[14] a) A. D. Becke, J. Chem. Phys. 1993, 98, 5648-5652; b) C. Lee, W. Yang, R. G. Parr, Phys. Rev. B 1998, 37, 785-789; c) S. H. Vosko, L. Wilk, M. Nusair, Can. J. Phys. 1980, 58, 1200-1211.

[15] S. Grimme, J. Antony, S. Ehrlich, H. Krieg, J. Chem. Phys. 2010, 132, 154104-154119.

[16] F. Weigend, R. Alhrichs, Phys. Chem. Chem. Phys. 2005, 7, 3297-3305.

[17] J. W. Mclver, A. K. Komornicki, A. K. J. Am. Chem. Soc. 1972, 94, 2625-2633.

[18] C. González, H. B. Schlegel, J. Phys. Chem. 1990, 94, 5523-5527.

[19] a) S. Miertuš, E. Scrocco, J. Tomasi, Chem. Phys. 1981, 55, 117-129; b) J. L. Pascual-Ahuir, E. Silla, I. Tuñón, J. Comp. Chem. 1994, 15 , 1127-1138; c) V. Barone, M. Cossi, J. Phys. Chem. A, 1998, 102, 19952001. 
Entry for the Table of Contents (Please choose one layout)

Layout 1:

\section{FULL PAPER}

\section{Domino $\alpha$-arylation/Michael} addition reactions: Sulfonates, sulfonamides and phosphonates are useful partners for the $\alpha$ arylation/Michael addition process leading to tetrahydroisoquinolines
Domino $\alpha$-arylation/Michael addition reactions

Daniel Solé, * Ferran Pérez-Janer, Yago García-Rodeja, and Israel Fernández*

Page No. - Page No.

Exploring New Partners for the Domino $\alpha$-Arylation/Michael Addition Reaction Leading to Tetrahydroisoquinolines 